\title{
Reproductive period, fecundity and histology of gonads of two cheirodontines (Ostariophysi: Characidae) with different reproductive strategies - insemination and external fertilization
}

\author{
Cristina L. C. Oliveira ${ }^{1}$, Clarice B. Fialho ${ }^{2}$ and Luiz R. Malabarba ${ }^{2}$
}

The reproductive period and fecundity of the inseminating cheirodontine Compsura heterura and of the externally fertilizing cheirodontine Odontostilbe pequira, from tropical and subtropical regions of Brazil, respectively, are described. The reproductive period of C. heterura lasted from January to April 2002, while O. pequira showed two reproductive periods, the first during September and October 2001 (spring), and the second between January and February 2002 (summer). Smaller classes of SL of females of $O$. pequira predominated in the second reproductive period, suggesting individuals born in the first period become shortly sexually mature, participating in the second reproductive period. In C. heterura, from a tropical region, temperature showed significant correlations with the variation in the gonadosomatic index (GSI) for both sexes, and rainfall showed significant correlation with the variation in the GSI only for females. In O. pequira, from a subtropical region, photoperiod was the only factor that showed significant correlations with the GSI variation in both sexes. The mean relative fecundity of $C$. heterura was 0.55 oocytes per milligram of total weight, similar to that of other cheirodontines with external fertilization, refuting the hypothesis, at least in Cheirodontinae, that insemination provides diminishing energy expenditure for the production of oocytes, due to a greater probability of fertilization. The mean relative fecundity of $O$. pequira was 0.8 oocytes per milligram of total weight, the largest known among cheirodontines. Spermatozoa were found inside the ovaries of maturating, mature and semi-spent females of $C$. heterura supporting the hypothesis of temporal separation between courtship and spawning. The largest relative weight of testis and the presence of sperm in maturing ovaries outside the reproductive period in $C$. heterura support the hypothesis that males of inseminating species make a greater investment in gonadal development than those externally fertilized.

São descritos o período reprodutivo e a fecundidade do queirodontíneo inseminador Compsura heterura e do queirodontíneo de fecundação externa Odontostilbe pequira, coletados nas regiões tropical e subtropical do Brasil, respectivamente. O período reprodutivo de $C$. heterura estendeu-se de janeiro a abril de 2002, enquanto que $O$. pequira apresentou duas etapas reprodutivas, a primeira de setembro a outubro de 2001 (primavera), e a segunda de janeiro a fevereiro de 2002 (verão). Classes de comprimento padrão menores predominaram no segundo período reprodutivo, sugerindo que indivíduos nascidos no primeiro período tornaram-se sexualmente maduros rapidamente, participando do segundo período reprodutivo. Em C. heterura, de região tropical, a temperatura apresentou correlações significativas com as variações de índice gonadossomático (IGS) em machos e fêmeas, e a pluviosidade somente para fêmeas. Em O. pequira, de região subtropical, o fotoperíodo foi único fator que apresentou correlação significativa com as variações de IGS em ambos os sexos. A fecundidade relativa média de $C$. heterura foi de 0,55 ovócitos por miligrama de peso total, semelhante a de outros queirodontíneos com fecundação externa, refutando a hipótese, pelo menos em Cheirodontinae, de que a inseminação permite a diminuição do gasto energético na produção de ovócitos devido a maior probabilidade de fertilização. A fecundidade relativa média de $O$. pequira foi de 0,8 ovócitos por miligrama de peso, a mais alta conhecida em Cheirodontinae. Foram encontrados espermatozóides em ovários em maturação, maduros e semi-esgotados em $C$. heterura. O maior peso relativo dos testículos e a presença de espermatozóides em ovários em maturação e fora do período reprodutivo em $C$. heterura suportam a hipótese que machos de espécies inseminadoras tem maior investimento no desenvolvimento gonadal do que em espécies de fertilização externa.

Key words: Inseminating, Compsurini, Cheirodontini, Compsura heterura, Odontostilbe pequira.

\footnotetext{
${ }^{1}$ Departamento de Ciências Biológicas, Universidade Estadual de Santa Cruz. Rodovia Ilhéus-Itabuna Km 16, $45662-900$ Ilhéus, BA, Brazil.crisbio2@gmail.com

${ }^{2}$ Departamento de Zoologia, Universidade Federal do Rio Grande do Sul. Av. Bento Gonçalves, 9500, 91501-970 Porto Alegre, RS, Brazil. cbfialho@via-rs.net, malabarb@ufrgs.br
} 


\section{Introduction}

Characidae is the largest family of Neotropical fishes, showing a high diversity in reproductive strategies among its representatives. Cheirodontinae is a subfamily of characid fishes abundant mainly in lentic and lowland waters, and inhabiting river drainages of Central and South America. The species are usually small, reaching a maximum of 30-40 mm standard length (Malabarba, 1998), or even miniature with less than $20 \mathrm{~mm}$ standard length (Bührnheim et al., 2008).

The subfamily Cheirodontinae is composed of two tribes, Cheirodontini and Compsurini, besides some genera considered incertae sedis. The tribe Compsurini, in which Compsura heterura Eigenmann, 1915 belongs, includes all the inseminating species of Cheirodontinae (Malabarba, 1998), characterized by transfer of sperm from the testis of the mature males to the ovaries of females, as described by Burns et al. (1997). The members of this tribe also show specialized organs in the caudal fin of the males that vary from the presence of modified scales to the presence of hypertrophied tissues apparently of glandular function (Malabarba \& Weitzman, 1999, 2000; Malabarba et al., 2004). Odontostilbe pequira (Steindachner, 1882) is a member of some basal genera of the cheirodontines that have little sexual dimorphism and are all externally fertilized (Malabarba, 1998; Bührnheim \& Malabarba, 2006).

Existing works on the reproductive biology of Cheirodontinae so far available are related to members of the tribe Cheirodontini, including Gelain et al. (1999) who studied aspects of the reproduction of Serrapinnus calliurus (Boulenger, 1900) from the arroio Ribeiro, Rio Grande do Sul State, Brazil (RS); Braun et al. (2000) who described the reproductive biology of Cheirodon ibicuhiensis Eigenmann 1915 from lagoa Fortaleza, RS; Oliveira et al. (2002), who estimated the reproductive period, type of spawning and a fecundity of $C$. ibicuhiensis from the arroio Ribeiro, RS; Silvano et al. (2003) who studied the reproductive period and fecundity of Serrapinnus piaba (Lütken, 1874) from the rio Ceará-Mirim, Rio Grande do Norte State, Brazil (RN); and Compsurini, by Azevedo et al. (2010), who described the reproductive biology and development of the gill gland in Macropsobrycon uruguayanae from the rio Ibicuí, Rio Grande do Sul, Brazil.

This work deals with the reproductive biology of one inseminating species of the tribe Compsurini, Compsura heterura, and one externally fertilized species of basal cheirodontine genera, Odontostilbe pequira. We describe the reproductive period and test its correlation with the abiotic data of two different regions of Brazil, one tropical and one subtropical. We additionally estimate the absolute and relative fecundity, comparing them with the reproductive strategies demonstrated by each species, and describe histologically the testis and ovaries.

\section{Material and Methods}

The specimens were collected with a beach seine-net with a $5 \mathrm{~mm}$ mesh. Compsura heterura was collected monthly from April 2001 to April 2002 in the rio Ceará-Mirim, municipality of Taipu (05'37'47’S 35³7'09'W), Rio Grande do Norte State, Brazil. The specimens of Odontostilbe pequira were obtained

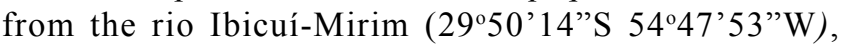
municipality of Cacequi, Rio Grande do Sul State, Brazil, during the period of April 2000 to March 2002. Voucher specimens were deposited in the Fish Collection of the Departamento de Zoologia, Universidade Federal do Rio Grande do Sul (UFRGS 8979, C. heterura; UFRGS 8990, O. pequira).

The specimens were fixed in $10 \%$ formalin and then transferred to $70 \%$ ethanol. Monthly, a random subsampling was made, always when possible consisting of 20 males and 20 females. The standard length (SL) in $\mathrm{mm}$ and total body weight (TW) in $g$ was determined for these specimens. Afterward, the individuals were dissected to remove and weigh the gonads and to determine macroscopically the stages of gonadal maturation. Later, histological sections were made to define more precisely the stages of gonadal maturation. The gonads were dehydrated in ethanol, cleared in xylol and embedded in glycolmethacrylate resin. These were cut in the sagital position with a thickness varying from 3 to $5 \mu \mathrm{m}$, and stained with hematoxylin-eosin (HE) or toluidin blue.

Two mature ovaries of $C$. heterura were examined in a Jeol scanning electron microscope (SEM), model JSM-5800. These were dehydrated in a BAL-TEC Critical Point Dryer, model CPD-030. The oocytes were supported on stubs, metalized in a BAL-TEC Sputter Coater, model SCD-005, with physical deposition of gold.

The reproductive period was estimated by the monthly variation of the mean values of the gonadosomatic index (GSI) and of the relative frequencies of the stages of gonadal maturation (Vazzoler, 1996).

Analysis of variance (ANOVA) was applied with INSTAT to determine whether there was a difference between the mean monthly GSI values. When a difference was found, Tukey's complementary test was used to identify which GSI means differed significantly.

Rainfall data were obtained from the "Empresa de Pesquisa Agropecuária do Rio Grande do Norte" and "Instituto Nacional de Meteorologia do Rio Grande do Sul." Sunrise and sunset times and photoperiod calculation were obtained using SkyMap, according to the coordinates of the sites of collection. Water temperatures were obtained with a thermometer at the time of collection. Spearman's nonparametric test was used to determine the correlations of the mean monthly GSI values with rainfall, photoperiod and temperature.

Absolute fecundities of the species were estimated by total count of the vitellogenic oocytes of mature females (26 females of $O$. pequira, 13 from spring and 13 from summer; 
and 20 females of C. heterura). The selected ovaries were placed in Gilson's solution modified by Simpson (1951) to allow dissociation of the internal mass, and the oocytes were separated for counting. Relative fecundity was estimated based on the number of oocytes per milligram of total weight, as suggested by Adebisi (1987). The Mann-Whitney test was used to determine if absolute fecundity and body size of the females of $O$. pequira collected in the first reproductive period (spring) differed from those of females collected in the second reproductive period (summer).

\section{Results}

A total of 1,111 specimens of $C$. heterura were collected, including 477 males and 634 females. Of these, 457 specimens were analyzed, including 233 males and 224 females. The smallest male examined measured $21.9 \mathrm{~mm}$ of standard length (SL) of and the largest $31.3 \mathrm{~mm} \mathrm{SL}$, while the smallest female measured $21.0 \mathrm{~mm} \mathrm{SL}$ and the largest $34.1 \mathrm{~mm} \mathrm{SL}$.

A total of 1,437 specimens of $O$. pequira were collected. Of these, 426 specimens were analyzed, including 176 males and 250 females. The smallest male measured $24.7 \mathrm{~mm}$ SL and the largest $40.5 \mathrm{~mm} \mathrm{SL}$, while the smallest female measured $23.2 \mathrm{~mm} \mathrm{SL}$ and the largest $44.9 \mathrm{~mm}$ SL.

Based on macroscopic and histological analyses, the following stages of maturation were characterized for the female gonads: maturing, mature and semi-spent. The gonads of the males were classified as immature, maturing and mature.

In the macroscopic analysis, the maturing females showed solid and compact gonads. At the beginning of this stage, the oocytes are opaque and small, but at the end the oocytes start turning more yellowish and the ovary begins to occupy a larger space in the abdominal cavity. In the histological analysis, initially early and mid primary growth oocytes are seen, and at the end of this stage some vitellogenic oocytes can be seen (Fig. 1a, b).

Mature females had large gonads, occupying the greater part of the abdominal cavity, with various vitellogenic oocytes easily visualized macroscopically. On histological analysis, the ovigerous lamellae were filled with various vitellogenic oocytes, pre-vitellogenic oocytes, some early primary growth oocytes and ovogonia (Fig. 1c, d).

Semi-spent females possess a more reduced ovary, similar to that in the final stage of maturation. On histological analysis, post-ovulatory follicles were seen, along with vitellogenic oocytes and early primary growth oocytes (Fig. 1e, f). There was also the presence of atresic follicles (vitellogenic oocytes that were not spawned but reabsorbed). The presence of these stages can be an indicator of multiple spawning for both species.

No fertilized oocytes or embryos in development were observed in the ovaries examined in $C$. heterura. The spermatozoa were found dispersed or in groups among the oocytes of maturing, mature and semi-spent $C$. heterura (Figs. $1 \mathrm{e}, \mathrm{f} ; 2)$. The three maturing females showing spermatozoa in the ovaries were collected in August, November and December.
The presence of spermatozoa was not observed in the ovaries of $O$. pequira.

The gonads of males classified as immature are transparent, very fine and only visible with a stereomicroscope. On histological analysis, only spermatogonia were seen (Fig. 3a).

Maturing males show rather thin gonads, with white coloration and visible without the help of a stereomicroscope. Initially, various spermatogonia, primary and secondary spermatocytes and few spermatids were observed, and at the end of this phase few spermatozoids were seen (Fig. 3b, c, d).

Gonads classified as mature show a more intense white coloration, have a greater volume and undulating borders, and can be clearly recognized without the help of a stereomicroscope. Histologically, all phases of spermatogenesis could be observed in the seminiferous tubules: spermatogonia, spermatocytes, spermatids and many spermatozoa (Fig. 3e, f). Mature testes of $C$. heterura are more developed than those of $O$. pequira. In $O$. pequira, the testis reached a maximum of $2 \%$ of total weight of the fish, while in $C$. heterura up to $6 \%$.

Based on the mean monthly GSI values (Fig. 4) and on the frequencies of the stages of gonadal maturation (Fig. 5), it was estimated that reproductive period of C. heterura in the rio Ceará-Mirim began in January extending up to April 2002, when higher values of the gonadosomatic index (GSI) were seen, in males as well as females (Fig. 4; Table 1). In this period, there was a greater frequency of mature individuals (Fig. 5b).

The monthly variation of the GSI means of the females of O. pequira showed two peaks, one in September 2001 and a second in February 2002 (Fig. 4; Table 2). Analysis of variance (ANOVA) demonstrated a significant difference between the monthly values of GSI. Afterward, the complementary Tukey's test confirmed that there was a significant difference in the mean GSI values observed between the two peaks, demonstrating the existence of two reproductive cycles, one during spring and the other in summer. Based on the MannWhitney test, there was a significant difference in the standard lengths of females and males between the first reproductive period (spring) and the second reproductive period (summer). The standard length of females of $O$. pequira that participated in the first period varied from $35.3 \mathrm{~mm}$ to $43.7 \mathrm{~mm}$ with a mean of $39.2 \mathrm{~mm}$, and the standard length of females that participated in the second period varied from $31.1 \mathrm{~mm}$ to $42.2 \mathrm{~mm}$ with a mean of $35.5 \mathrm{~mm}$ (Fig. 6). The standard length of males of $O$. pequira that participated in the first period varied from 28.7 $\mathrm{mm}$ to $39.4 \mathrm{~mm}$ with a mean of $35.6 \mathrm{~mm}$, and the standard length of males that participated in the second period varied from $30 \mathrm{~mm}$ to $37.6 \mathrm{~mm}$ with a mean of $33.7 \mathrm{~mm}$.

Spearman's non-parametric test demonstrated a significant correlation between rainfall and GSI of females of $C$. heterura $(r=0.6355 ; p=0.0196)$. The same did not hold true for rainfall and GSI of males $(r=0.5172 ; p=0.0703)$. Spearman's test was significant for the correlation between temperature and GSI of males $(\mathrm{r}=0.8831 ; \mathrm{p}<0.0001)$ and females $(\mathrm{r}=0.8501 ; \mathrm{p}=$ $0.0002)$. The correlation between photoperiod and GSI was 

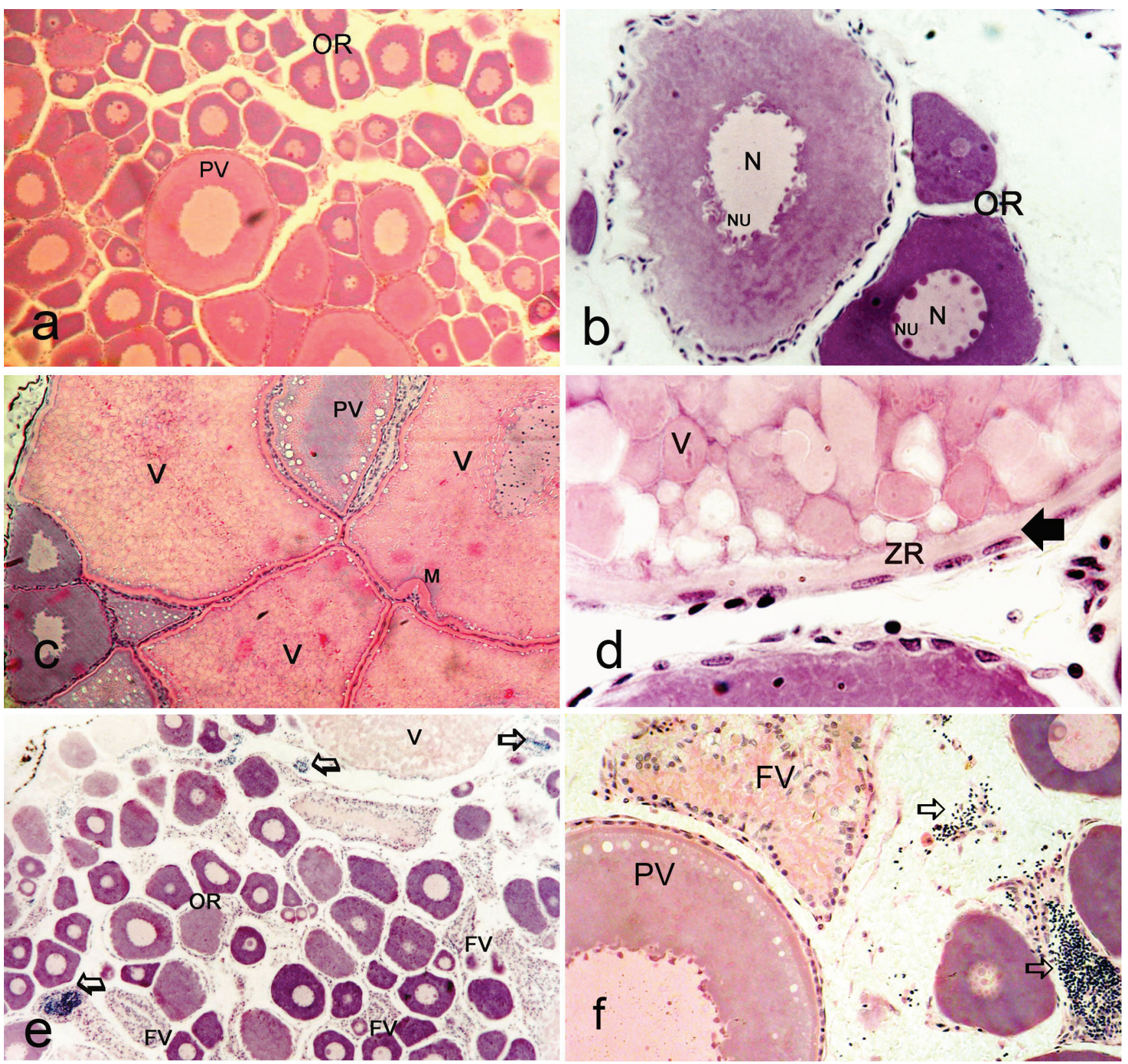

Fig. 1. Histology of ovaries of Compsura heterura at different stages of maturation: maturing $(\mathbf{a}, \mathbf{b})$, mature $(\mathbf{c}, \mathbf{d})$ and semispent $(\mathbf{e}, \mathbf{f})$. Black arrow - follicular cells, EZ and white arrow - spermatozoa, FV - post-ovulatory follicles, M - micropile, N nucleus, NU - nucleolus, OR - early primary growth oocytes, PV - Previtellogenic oocytes, V - vitellogenic oocyte, ZR - radiate zone. Magnification 10x (a, e), 20x (b, c), 100x (d, f).

not significant, for males $(\mathrm{r}=0.2531 ; \mathrm{p}=0.4041)$ as was well as for females $(\mathrm{r}=-0.0137 ; \mathrm{p}=0.9644)$.

In $O$. pequira, Spearman's non-parametric test demonstrated that there was a significant correlation between GSI and photoperiod for females $(\mathrm{r}=0.7692 ; \mathrm{p}=0.0034)$ and males $(\mathrm{r}=0.6355 ; \mathrm{p}=0.0196)$. There was no correlation between rainfall and GSI of females $(r=-0.2937 ; p=0.3541)$ and males $(\mathrm{r}=-0.3566 ; \mathrm{p}=0.2551)$. The correlation between temperature and GSI of males $(r=0.2242 ; \mathrm{p}=0.4837)$ and females $(\mathrm{r}=0.5604 ; \mathrm{p}=0.0581)$ was also not significant.

The absolute fecundity of $C$. heterura varied from 218 to
618 oocytes for females of $25.8 \mathrm{~mm}$ and $32.0 \mathrm{~mm} \mathrm{SL}$, respectively. The mean absolute fecundity was $434 \pm 112$ oocytes and the mean relative fecundity was 0.55 oocytes per milligram of body weight (Fig. 6). The absolute fecundity of $O$. pequira varied from 470 to 1,390 oocytes, considering females of $31.5 \mathrm{~mm}$ and $39.0 \mathrm{~mm} \mathrm{SL}$, respectively (Fig. 7). The Mann-Whitney test demonstrated that there was no significant difference for absolute fecundity values between the first and second reproductive periods described for $O$. pequira, where the mean was $795 \pm 262$ oocytes. The relative fecundity was 0.8 oocytes per milligram of body weight. 


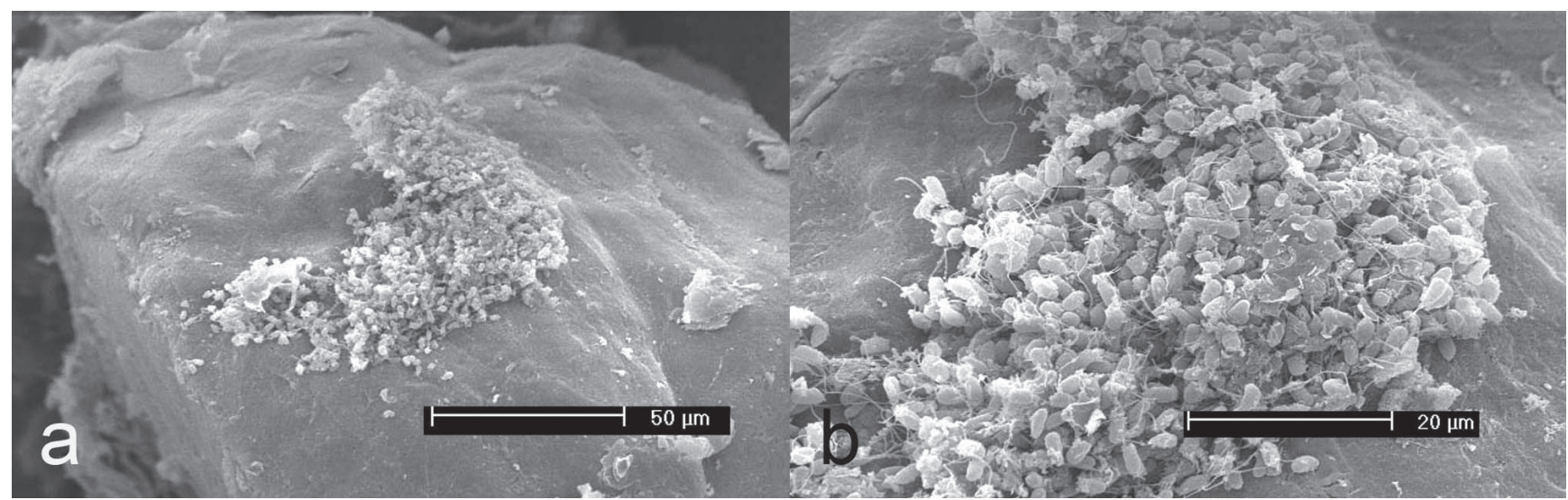

Fig. 2. Scanning Electron Micrography of an oocyte of Compsura heterura from an ovary critical-point dried and crushed with a needle on a stub, showing the spermatozoa observed over an oocyte (a), and an amplified image of these spermatozoa (b).

\section{Discussion}

Abiotic factors such as photoperiod, temperature and rainfall, as well as biotic factors such as availability of food, usually lead to reproductive events in the majority of species, influencing differently each species according to their reproductive strategies, physiological characteristics and genealogical histories (Azevedo, 2000). The reproductive period can be seen as the product of numerous biotic and abiotic stimuli which exert long-term effects on ovarian growth and short-term effects at the end of maturation of the oocytes and ovulation (Potts \& Wootton, 1984).

For tropical fishes, the availability of food plays an essential role in determining the reproductive rhythm, while photoperiod and temperature do not have a determinant role as limiting factors in reproduction (Vazzoler \& Menezes, 1992). In these environments, the availability of food varies fundamentally with alterations in rainfall. Thus, the beginning of rains augments rapidly the level of nutrients, leading to an increase in productivity and, as a consequence, to the increase in the availability of food (Vazzoler \& Menezes, 1992). In this manner, for the reproductive period of species of fishes of low latitude, such as in the northeast of Brazil, reproduction is generally associated with elevation in rainfall, along with temperature, which provide increased amounts of nutrients for adults and larvae. This seems to be true for females of $C$. heterura that showed a positive correlation between GSI and rainfall, and also a positive correlation of GSI and temperature for both sexes. The correlation between GSI of females and rainfall was also observed by Silvano et al. (2003) for Serrapinnus piaba collected in the same river and same period along with the specimens of $C$. heterura studied herein.

On the other hand, the reproductive period of the species of fish of the south of Brazil, where periods of lower and higher rainfall are not clearly demarcated, is generally associated with photoperiod, as demonstrated for O. pequira, in which both sexes showed a positive correlation between GSI and photoperiod only. The difference between the longest length of day and the shortest day in the location where $C$. heterura were collected is only $39 \mathrm{~min}$, but more than $232 \mathrm{~min}$ at the site of collection of $O$. pequira. The association of the reproductive period with photoperiod was found to be similar in the characids Diapoma speculiferum studied by Azevedo et al. (2000) and Aphyocharax anisitsi studied by Gonçalves et al. (2005) at relatively high latitudes $\left(30^{\circ} 22^{\prime} 62^{\prime \prime} \mathrm{S}\right.$ and $30^{\circ} 22^{\prime} 27^{\prime}$ 'S, respectively). In various vertebrates, melatonin is involved in the biological rhythm and in seasonal sexual activity. Many species attain the reproductive condition when the days become longer, because the exposure to light inhibits the release of melatonin, a hormone of the pineal gland, which inhibits steroidogenic activity of the gonads. The increase in light is sensed by pineal photoreceptors present in the epidermis of fish, which carry this information to the pineal gland. The signals are finally transmitted to the hypothalamus which controls the secretion of melatonin. As this hormone is an inhibitor of reproduction, the reduction of its level in the circulation, due to an increase in daylight hours, makes it possible for these individuals to undergo maturation. The hypothalamus also secrets hormones that stimulate the adenohypophysis to secrete gonadotropins which initiate gonadal development (Gonçalves et al., 2005).

Fecundity depends on the volume of the celomatic cavity available for harboring the mature oocytes and on the size (volume) of the oocytes (Vazzoler, 1996). Fecundity and the diameter of the mature oocytes vary greatly between reproductive periods and among individuals of the same size in the same reproductive period (Vazzoler, 1996). According to Nikolsky (1969), the variation in fecundity of species that occupy different locations, can be related to the supply of food, size of first gonadal maturation, longevity, population density, temperature and latitude. Besides, there are other factors that can interfere with fecundity, for example, the type of fertilization and care for the offspring.

Based on the observation that inseminating species of the subfamily Glandulocaudinae (now Stevardiinae and Glandulocaudinae) show relatively lower fecundity compared to other characids with external fertilization, Azevedo (2000), Azevedo et al. (2000) and Burns \& 


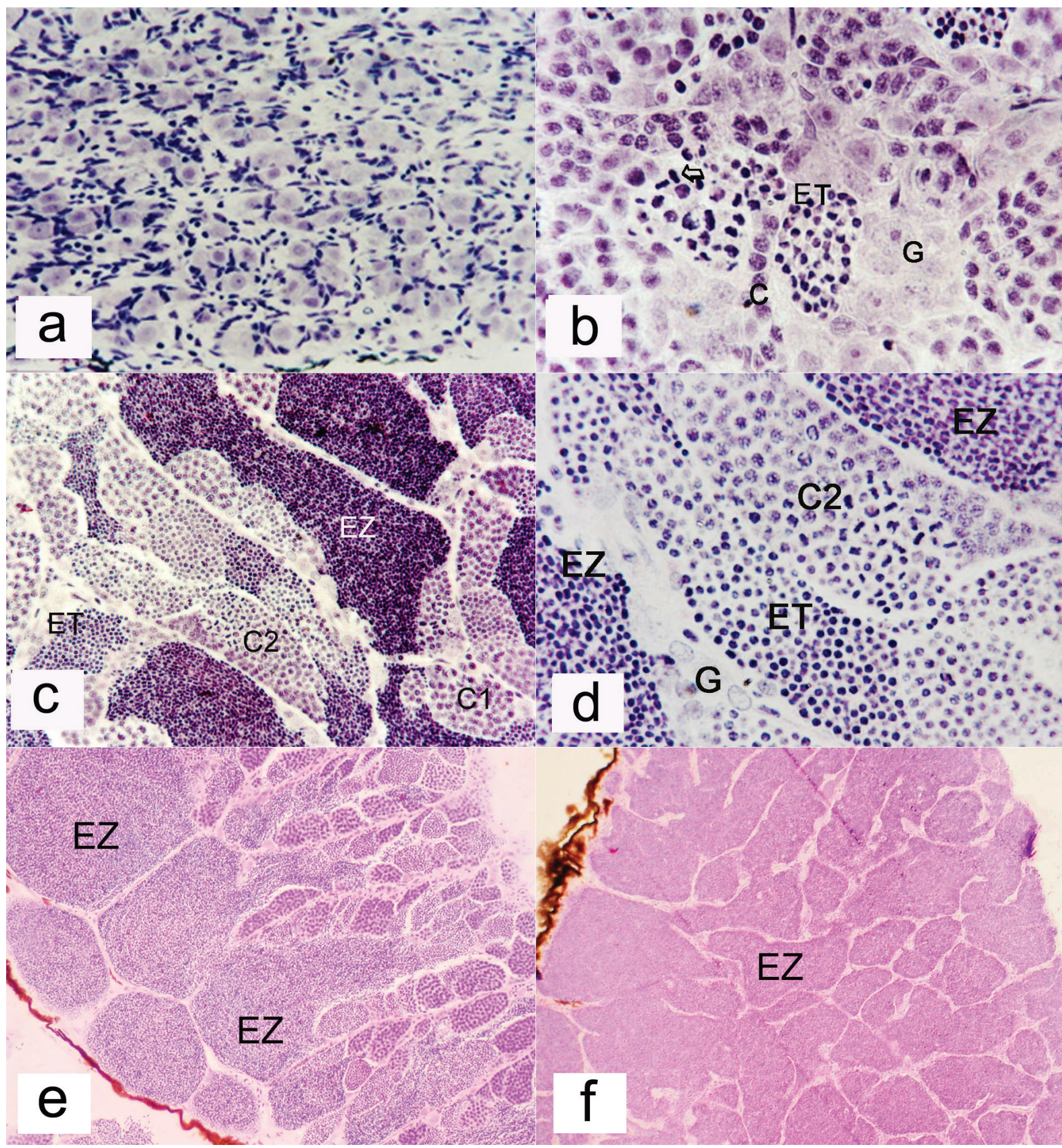

Fig. 3. Histology of testis of Compsura heterura $(\mathbf{a}, \mathbf{c}, \mathbf{d})$ and Odontostilbe pequira $(\mathbf{b})$ at different stages of maturation: immature (a), maturing (b, c, d) mature (e, f). Arrow - cell division, C - spermatocytes, $\mathrm{C} 1$ - primary spermatogonia, $\mathrm{C} 2$ secondary spermatogonia, ET - spermatids, EZ - spermatozoa, G - spermatogonia. Magnification 40x (a, c), 100x (b, d), 20x (e, f).

Weitzman (2005) suggested that insemination provides a greater probability of fertilization, diminishing energy expenditure for the production of oocytes. The inseminating $C$. heterura shows relative fecundity higher than those of the inseminating species of Stevardiinae and Glandulocaudinae (Table 3). Compsura heterura also has approximately the same relative fecundity than that of the inseminating M. uruguayanae and similar to that of other cheirodontines with external fertilization (e.g., Cheirodon ibicuhiensis). Similar values of relative fecundity among inseminating and externally fertilized species refutes the hypothesis, at least in Cheirodontinae, that insemination provides diminishing energy expenditure for the production of oocytes, due to a greater probability of 

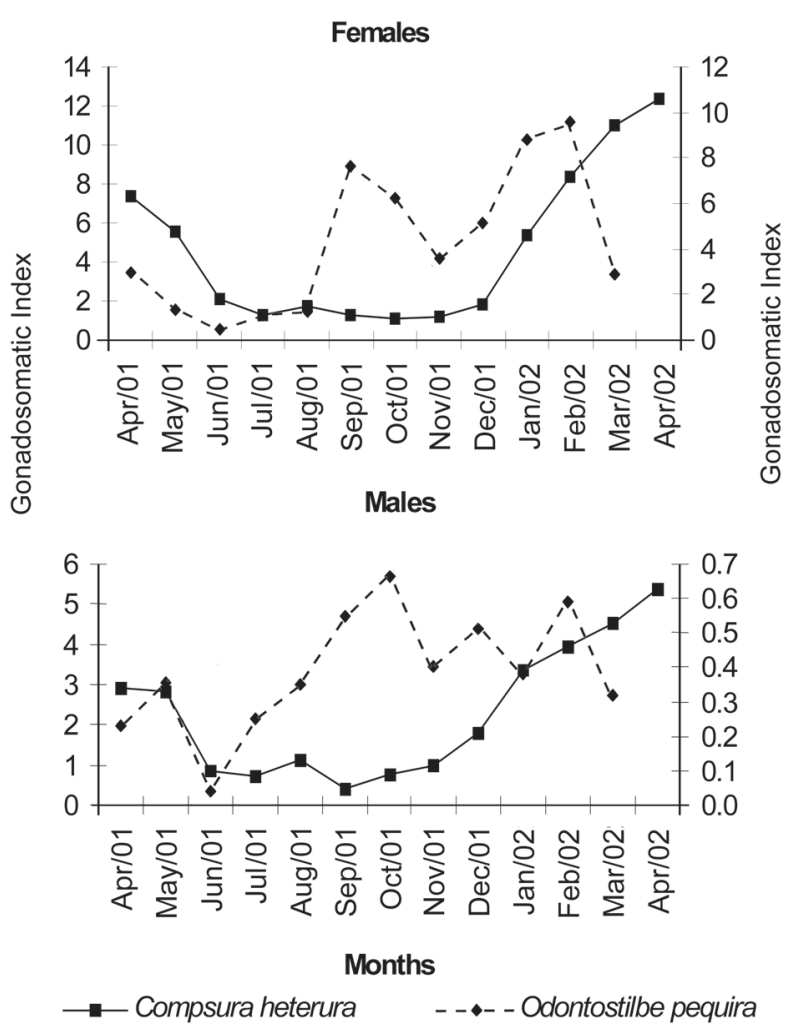

Fig. 4. Monthly variation of the mean of the gonadossomatic index (GSI) for females and males of Compsura heterura and of Odontostilbe pequira collected in the rio Ceará-Mirim, RN, and in the rio Ibicuí-Mirim, RS, from April 2001 to April 2002.

fertilization. The mean relative fecundity of $O$. pequira was the largest observed among inseminating and externally fertilizing cheirodontines (Table 3).

Vazzoler (1996) stated that fecundity also varies with the size of the female, increasing with growth, and that this is more related to length than to age of the individual. This was not observed for $O$. pequira. The larger females of $O$. pequira, probably the older ones, participated in the first reproductive period (spring), which occurred from September to October 2001. Some large females and a greater number of small females participated in the second reproductive period (summer) which occurred from January to February 2002. The individuals born in the spring reproductive period apparently developed rapidly and become sexually mature in 4 to 6 months, and participated in the second reproductive period. The relation between standard length and absolute fecundity of the females of $O$. pequira was low $(\mathrm{r}=0.45)$. Means of absolute and relative fecundities were greater in the second reproductive period (summer), when smaller classes of SL of females predominated (Fig. 6). Apparently, these females that participate for the first time in reproduction tend to invest more in the production of oocytes.

The testes of mature males of $C$. heterura are more developed than those of $O$. pequira, being as much as $6 \%$ of the total weight of the fish. In O.pequira, the testes reach a maximum of $2 \%$ of total weight. Among other externally fertilized cheirodontines, the testis can reach as much as $1.8 \%$ of total weight in C. ibicuhiensis (Oliveira et al., 2002), up to approximately $2 \%$ in S. calliurus (Gelain et al., 1999), as much as $2.8 \%$ in $S$. heterodon (P. M. Zamberlan, pers.

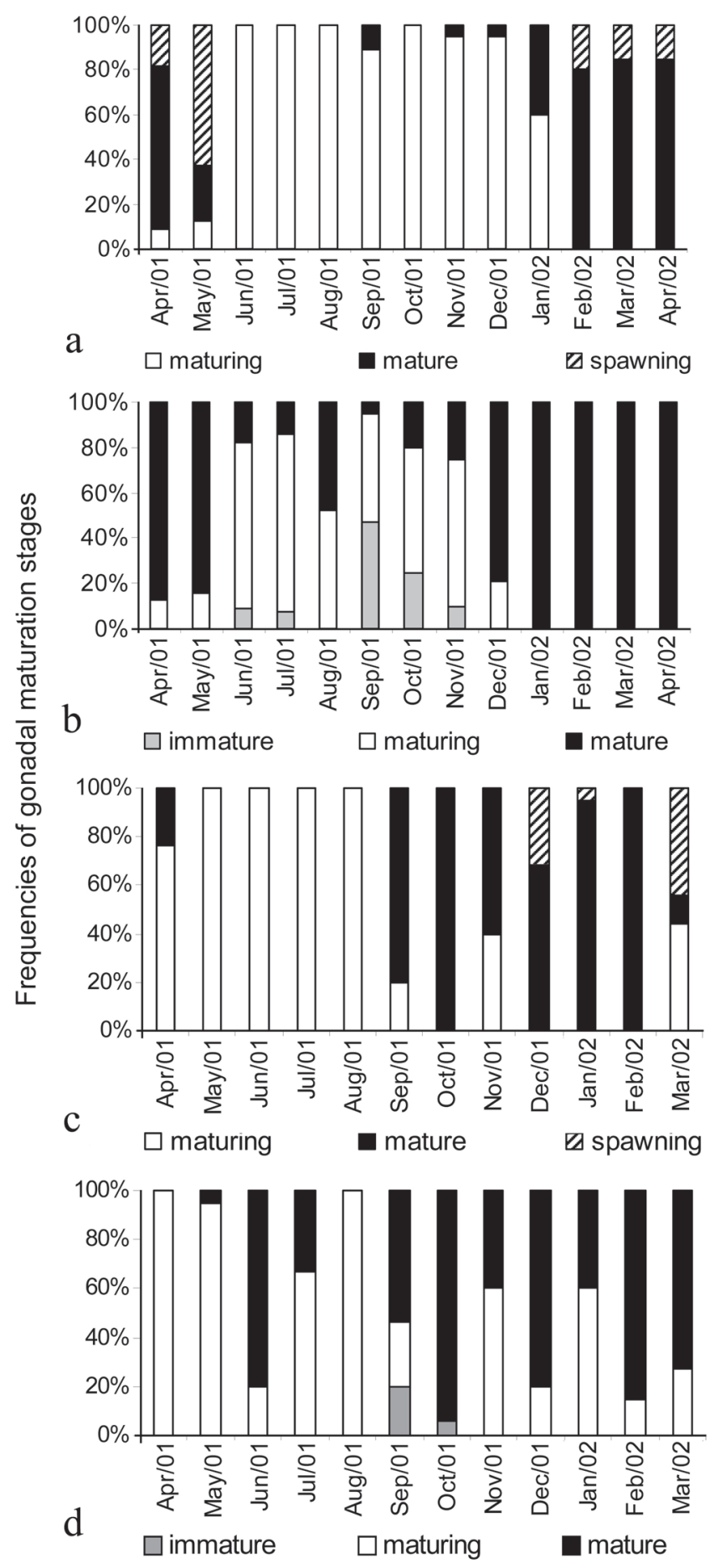

Fig. 5. Monthly distribution of the frequencies of gonadal maturation stages of females (a) and males (b) of Compsura heterura and females (c) and males (d) of Odontostilbe pequira collected in the rio Ceará-Mirim, RN, and in the rio IbicuíMirim, RS, from April 2001 to April 2002. 
Table 1. Monthly variation of the means of the gonadossomatic index (GSI) ( \pm standard deviation) for males and females of Compsura heterura and abiotic data (rainfall, day length and temperature). $\mathrm{n}=$ number of sample individuals monthly.

\begin{tabular}{cccccc}
\hline \multirow{2}{*}{ Months } & \multicolumn{2}{c}{ GSI \pm standard deviation } & \multirow{2}{*}{ Rainfall $(\mathrm{mm})$} & \multirow{2}{*}{ Day length (min.) } & \multirow{2}{*}{ Temperature $\left({ }^{\circ} \mathrm{C}\right)$} \\
\cline { 2 - 3 } & males $(\mathrm{n})$ & females $(\mathrm{n})$ & & 716 & 32.65 \\
Apr/2001 & $2.915 \pm 1.464(16)$ & $7.385 \pm 3.139(23)$ & 192.5 & 712 & 27 \\
May/2001 & $2.800 \pm 1.331(19)$ & $5.529 \pm 1.376(16)$ & 11.6 & 708 & 26 \\
Jun/2001 & $0.856 \pm 1.202(11)$ & $2.115 \pm 1.859(2)$ & 108.3 & 709 & 23.5 \\
Jul/2001 & $0.728 \pm 0.671(14)$ & $1.252 \pm 0.451(5)$ & 37 & 714 & 24.5 \\
Aug/2001 & $1.114 \pm 0.956(21)$ & $1.705 \pm 1.310(19)$ & 20.4 & 724 & 21.5 \\
Sep/2001 & $0.410 \pm 0.622(20)$ & $1.271 \pm 1.689(20)$ & 0 & 733 & 24 \\
Oct/2001 & $0.769 \pm 0.897(20)$ & $1.070 \pm 0.355(19)$ & 0 & 741 & 24.5 \\
Nov/2001 & $0.975 \pm 0.883(20)$ & $1.196 \pm 0.263(20)$ & 18.2 & 747 & 28.75 \\
Dec/2001 & $1.800 \pm 1.004(20)$ & $1.832 \pm 0.746(20)$ & 3.6 & 742 & 27.5 \\
Jan/2002 & $3.341 \pm 0.556(20)$ & $5.382 \pm 2.817(20)$ & 103 & 734 & 29.5 \\
Feb/2002 & $3.924 \pm 0.636(20)$ & $8.363 \pm 2.794(20)$ & 57.8 & 728 & 30 \\
Mar/2002 & $4.516 \pm 0.808(20)$ & $11.026 \pm 3.084(20)$ & 180.1 & 716 & \\
Apr/2002 & $5.375 \pm 0.554(20)$ & $12.353 \pm 4.283(20)$ & 36 & & \\
\hline
\end{tabular}

Table 2. Monthly variation of the means of the gonadossomatic index (GSI) ( \pm standard deviation) for males and females of Odontostilbe pequira and abiotic data (rainfall, day length and temperature). $\mathrm{n}=$ number of sample individuals monthly.

\begin{tabular}{cccccc}
\hline \multirow{2}{*}{ Months } & \multicolumn{2}{c}{ GSI \pm standard deviation } & \multirow{2}{*}{ Rainfall $(\mathrm{mm})$} & \multirow{2}{*}{ Day length $(\mathrm{min})}$. & \multirow{2}{*}{ Temperature $\left({ }^{\circ} \mathrm{C}\right)$} \\
\cline { 2 - 3 } & males (n) & females (n) & & & 24.1 \\
Apr/2001 & $0.230 \pm 0.050(6)$ & $3.833 \pm 1.955(30)$ & 388.5 & 696 & 17.0 \\
May/2001 & $0.353 \pm 0.231(20)$ & $1.301 \pm 0.480(22)$ & 196.8 & 641 & 22.0 \\
Jun/2001 & $0.044 \pm 0.015(4)$ & $0.501 \pm 0.245(20)$ & 319.2 & 614 & 17.7 \\
Jul/2001 & $0.249 \pm 0.073(9)$ & $1.069 \pm 0.196(20)$ & 162.8 & 617 & 20.1 \\
Aug/2001 & $0.349 \pm 0.119(3)$ & $1.250 \pm 0.367(17)$ & 116.9 & 648 & 17.8 \\
Sep/2001 & $0.549 \pm 0.105(15)$ & $7.635 \pm 3.675(20)$ & 430.4 & 722 & 22.5 \\
Oct/2001 & $0.662 \pm 0.154(17)$ & $6.205 \pm 2.186(22)$ & 181.6 & 778 & 22.9 \\
Nov/2001 & $0.402 \pm 0.119(20)$ & $3.546 \pm 2.827(20)$ & 174.5 & 836 & 27.0 \\
Dec/2001 & $0.512 \pm 0.128(20)$ & $5.136 \pm 1.789(20)$ & 63.6 & 846 & 26.0 \\
Jan/2002 & $0.382 \pm 0.086(20)$ & $8.813 \pm 2.069(20)$ & 84.8 & 817 & 24.0 \\
Feb/2002 & $0.589 \pm 0.086(20)$ & $9.611 \pm 2.185(20)$ & 23.4 & 808 & 22.5 \\
Mar/2002 & $0.319 \pm 0.137(22)$ & $2.878 \pm 2.184(22)$ & 342.6 & 753 &
\end{tabular}

comm.), and up to $1.7 \%$ in S. piaba (Silvano et al., 2003). In the externally fertilized Aphyocharax anisitsi of the Aphyocharacinae studied by Gonçalves et al. (2005), the testis reaches a maximum of $1.09 \%$ of total weight. A greater development of the testis has also been observed in inseminating species of the subfamilies Stevardiinae and Glandulocaudinae. In males of the stevardiine Diapoma speculiferum, the testis can reach up to $3 \%$ of the total body weight (Azevedo et al., 2000); in the glandulocaudines Mimagoniates rheocharis up to $4.5 \%$ and Mimagoniates microlepis up to $7 \%$ of total body weight (Azevedo, 2000). Unlike species with external fertilization, males of inseminating species apparently make a greater investment in gonadal development, which can be associated with the need of always being available for insemination even outside the time of spawning. The males with greater production of spermatozoa and over longer periods would be more effective in the insemination of a larger number of females and in the production of offspring. In fact, we found one male of $C$. heterura collected in August, outside of the reproductive period described herein, showing the most advanced testis stage under histological examination.

Spermatozoa were found in the maturing ovaries of two C. heterura females, collected in November and December, that is, 1 to 2 months before the reproductive period.
Apparently, C. heterura females are receptive to courtship and insemination even before being mature and, thus, can be inseminated outside the reproductive period since adult males are active the entire year. Spermatozoa were present also in a maturing female $(\mathrm{SL}=27.1 \mathrm{~mm}, \mathrm{GSI}=4.3)$ captured in August 2001. The ovaries of this female, however, contained various early primary growth oocytes, some vitellogenic oocytes and post-ovulatory follicles, which

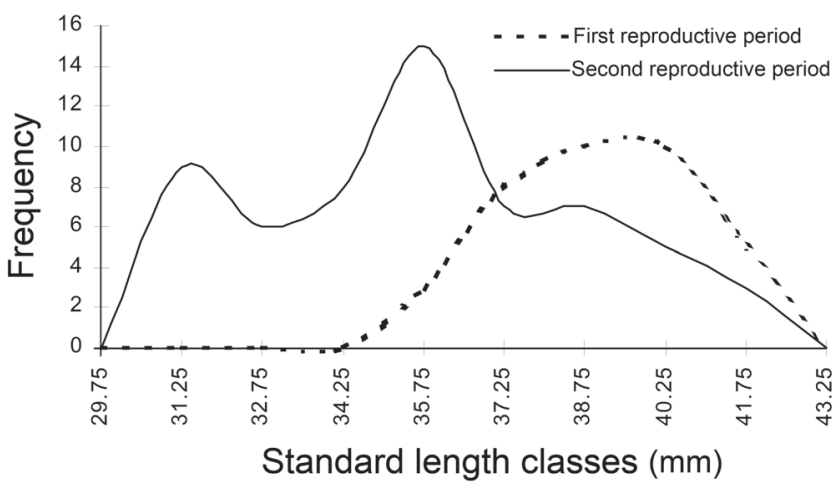

Fig. 6. Distribution of the absolute frequencies of the standard lengths of females of Odontostilbe pequira in the first (September/October) and second (January/February) reproductive periods. 
Table 3. Comparative data of absolute fecundity and relative fecundity of glandulocaudine, stevardiine, inseminating cheirodontine and externally fertilized cheirodontine.

\begin{tabular}{lccc}
\hline \multicolumn{1}{c}{ Species } & Reference & Absolute fecundity & Relative fecundity \\
\hline Glandulocaudinae (inseminating) & & & \\
Mimagoniates microlepis & Azevedo, 2000 & 109 & 0.27 \\
$\begin{array}{l}\text { Mimagoniates rheocharis } \\
\text { Stevardiinae (inseminating) }\end{array}$ & Azevedo, 2000 & 421 & 0.35 \\
$\begin{array}{l}\text { Pseudocorynopoma doriae } \\
\text { Diapoma speculiferum }\end{array}$ & F. A. G. Melo (unpubl. data) & 979 & 0.34 \\
\hline Cheirodontinae inseminating & Azevedo et al., 2000 & 491 & 0.41 \\
Compsura heterura & This paper & 434 & 0.55 \\
Macropsobrycon uruguayanae & Azevedo et al., 2010 & 191 & 0.54 \\
\hline Cheirodontinae externally fertilized & & & \\
Cheirodon ibicuhiensis & Oliveira et al., 2002 & 513 & 0.5 \\
Serrapinnus calliurus & Gelain et al., 1999 & 426 & 0.61 \\
Odontostilbe pequira & This paper & 795 & 0.8 \\
Serrapinnus piaba & Silvano et al., 2003 & 441 & 0.74 \\
\hline
\end{tabular}

indicates gonads that have undergone a period of spawning and are maturing for the next reproductive cycle. In the specific case of this female, we can propose two hypotheses: the presence of insemination outside the reproductive period or the existence of remaining spermatozoa from the previous reproductive period.

Azevedo et al. (2000) found spermatozoa in the ovaries of maturing females of D. speculiferum and Azevedo et al. (2010) within the ovaries of Macropsobrycon uruguayanae in different stages of gonadal maturation during most collected months. Burns \& Weitzman (2005) also discovered spermatozoa in the ovaries of maturing females of Gephyrocharax valenciae and Brittanichthys axelrodi. To these authors, this finding suggested that insemination could truly occur before the oocytes were mature. The

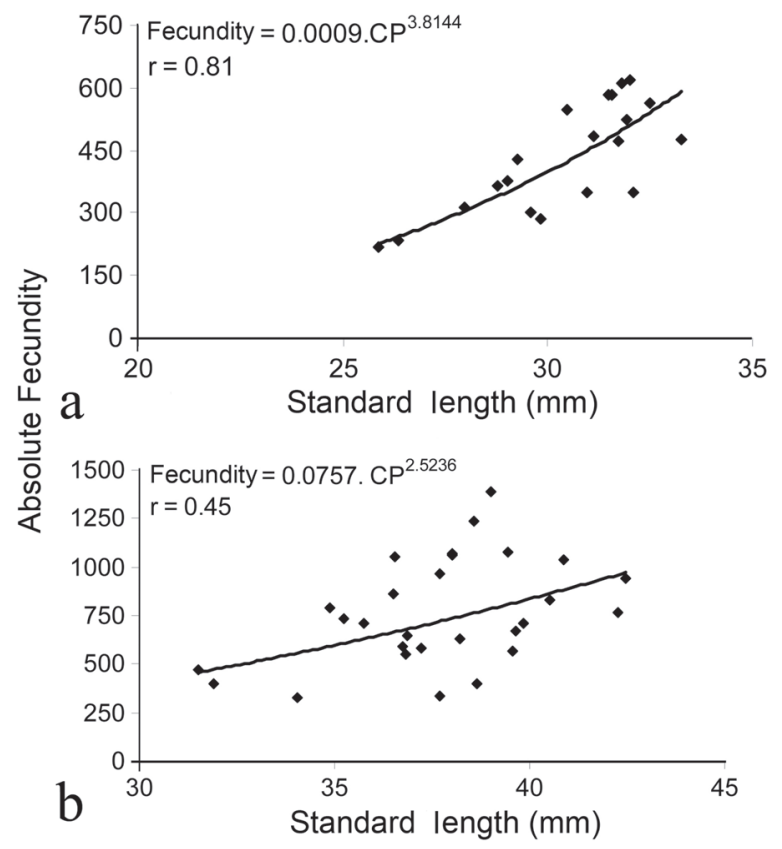

Fig. 7. Relation between absolute fecundity and standard length of females of Compsura heterura (a), from rio CearáMirim, RN, and of Odontostilbe pequira (b) from rio IbicuíMirim, RS. observation of this strategy of insemination before maturation in species not phylogenetically related $(C$. heterura in Cheirodontinae; D. speculiferum and $G$. valenciae in Stevardiinae; and the characid incertae sedis $B$. axelrodi) indicates the independent acquisition (or evolution) of this strategy in these groups.

It is likely that the spermatozoa of inseminating species spend a long time in the ovary of still-maturing females. According to Kutaygil (1959), females of Corynopoma riisei are capable of depositing fertilized oocytes 7 to 10 months after mating. The advantage of courtship and insemination before the reproductive period seems to be related to the spatial and temporal separation of maturation between males and females, according to Burns et al. (1997), also allowing the delay of oviposition until environmental conditions are favorable for the larvae.

\section{Acknowledgements}

The authors wish to thank Tatiana Dias from Universidade Federal do Rio Grande do Sul, Brazil, and Hélio Gurgel from Universidade Federal do Rio Grande do Norte, Brazil, for their collecting support. This research was supported by the Conselho Nacional de Desenvolvimento Científico e Tecnológico - CNPq, Brazil (proc. 478002/2006-8 and 476821/2003-7).

\section{Literature Cited}

Adebisi, A. A. 1987. The relationships between fecundities, gonadosomatic indices and egg sizes of some fishes of Ogun River, Nigeria. Archiv für Hydrobiologie, 111: 151-156.

Azevedo, M. A., L. R. Malabarba \& C. B. Fialho. 2000. Reproductive biology of the inseminated Glandulocaudine Diapoma speculiferum Cope, (Actinopterygii: Characidae). Copeia, 2000(4): 983-989.

Azevedo, M. A. 2000. Biologia reprodutiva de dois glandulocaudíneos com inseminação, Mimagoniates microlepis e Mimagoniates rheocharis (Teleostei: Characidae), e características de seus ambientes. Unpublished M.Sc. Dissertation, Universidade Federal do Rio Grande do Sul, Porto Alegre, $84 p$. 
Azevedo, M. A., L. R. Malabarba \& J. R. Burns. 2010. Reproductive biology and development of gill glands in the inseminating characid, Macropsobrycon uruguayanae Eigenmann, 1915 (Cheirodontinae: Compsurini). Neotropical Ichthyology, 8(1): 87-96.

Braun, A. S., D. S. Lewis \& N. F. Fontoura. 2000. Biologia reprodutiva de Cheirodon ibicuhiensis (Eigenmann, 1915) na lagoa Fortaleza, Cidreira, Rio Grande do Sul, Brasil (Teleostei: Characidae: Cheirodontinae). Comunicações do Museu de Ciências e Tecnologia da PUCRS, série Zoologia, 13(2): 159-166.

Bührnheim, C. M., T. P. Carvalho, L. R. Malabarba \& S. H. Weitzman. 2008. A new genus and species of characid fish from the Amazon basin - the recognition of a relictual lineage of characid fishes (Ostariophysi: Cheirodontinae: Cheirodontini). Neotropical Ichthyology, 6(4): 663-678.

Bührnheim, C. M. \& L. R. Malabarba. 2006. Redescription of the type species of Odontostilbe Cope, 1870 (Teleostei: Characidae: Cheirodontinae), and description of three new species from the Amazon basin. Neotropical Ichthyology, 4(2): 167-196.

Burns, J. R. \& S. H. Weitzman 2005. Insemination in ostariophysan fishes. Pp 107-134. In: Uribe, M. C. \& H. J. Grier (Eds.). Viviparous Fishes. Homestead, New Life Publications, 603p.

Burns, J. R., S. H. Weitzman \& L. R. Malabarba. 1997. Insemination in eight species of Cheirodontine fishes (Teleostei: Characidae: Cheirodontinae). Copeia, 1997(2): 433-438.

Gelain, D., C. B. Fialho \& L. R. Malabarba. 1999. Biologia reprodutiva de Serrapinnus calliurus (Boulenger, 1900) (Characidae, Cheirodontinae) do arroio Ribeiro, Barra do Ribeiro, RS, Brasil. Comunicações do Museu de Ciências e Tecnologia da PUCRS, 12: 72-82.

Gonçalves, T. K, M. A. Azevedo \& L. R. Malabarba. 2005. Reproductive biology and development of sexually dimorphic structures in Aphyocharax anisitsi (Ostariophysi: Characidae). Neotropical Ichthyology, 3(3): 433-438.

Kutaygil, N. 1959. Insemination, sexual differentiation and secondary sex characters in Stevardia albipinnis Gill. Hidrobiologie Istanbul Universitat Fen Fakultesi Mecumuasi Serie B, 24: 93-128.
Malabarba, L. R. 1998. Monophyly of the Cheirodontinae, characters and major clades (Ostariophysi: Characidae). Pp. 193-233. In: Malabarba, L. R., R. E. Reis, R. P. Vari, Z. M. S. Lucena \& C. A. S. Lucena (Eds.). Phylogeny and Classification of Neotropical Fishes. Porto Alegre, Edipucrs, 603p.

Malabarba, L. R., F. C. T. Lima \& S. H. Weitzman. 2004. A new species of Kolpotocheirodon (Teleostei: Characidae: Cheirodontinae: Compsurini) from Bahia, Northeastern Brazil, with new diagnosis of the genus. Proceedings of the Biological Society of Washington, 117(3): 317-329.

Malabarba, L. R. \& S. H. Weitzman. 1999. A new genus species of South American fishes (Teleostei: Characidae: Cheirodontinae) with a derived caudal-fin, including comments about inseminating cheirodontines. Proceedings of the Biological Society of Washington, 112(2): 411-432.

Malabarba, L. R. \& S. H. Weitzman. 2000. A new genus and species of inseminating fishes (Teleostei: Characidae: Compsurini) from South America with uniquely derived caudal-fin dermal papillae. Proceedings of the Biological Society of Washington, 113(2): 269-283.

Nikolsky, G. V. 1969. Theory of fish population dynamics. Edinburgh, Oliver \& Boyd Ltda, 323p.

Oliveira, C. L. C., C. B. Fialho \& L. R. Malabarba. 2002. Período reprodutivo, desova e fecundidade de Cheirodon ibicuhiensis Eigenmann, 1915 (Ostariophysi: Characidae) do arroio Ribeiro, Rio Grande do Sul, Brasil. Comunicações do Museu de Ciências e Tecnologia da PUCRS, série Zoologia, 15(1): 3-14.

Potts, G. W. \& M. N. Wooton. 1984. Fish reproduction: strategies and tatics. London, Academic Press, 410p.

Silvano, J., C. L. C. Oliveira, C. B. Fialho \& H. C. B. Gurgel. 2003. Reproductive period and fecundity of Serrapinnus piaba. Neotropical Ichthyology, 1(1): 61-66.

Simpson, A. C. 1951. The fecundity of the place. Fishery Investigations, 17(5): 27.

Vazzoler, A. E. A. M. 1996. Biologia da reprodução de peixes teleósteos: teoria e prática. Maringá, Eduem, 169p.

Vazzoler, A. E. A. M. \& N. A. Menezes. 1992. Síntese de conhecimentos sobre o comportamento reprodutivo dos Characiformes da América do Sul (Teleostei, Ostariophysi). Revista Brasileira de Biologia, 52(4): 627-640. 